\author{
Info Artikel Diterima Oktober 2020 \\ Disetujui Desember 2020 \\ Dipublikasikan April 2021
}

\title{
PENGARUH DENSITAS BAHAN TERHADAP MUTU BRIKET ARANG TEMPURUNG KELAPA
}

\section{THE EFFECT OF MATERIAL DENSITY ON THE QUALITY OF COCONUT CHARCOAL BRIQUETTE}

\author{
Zulham Sirajuddin \\ Program Studi Agribisnis \\ Fakultas Pertanian Universitas Ichsan Gorontalo \\ Email: zulham.sirajuddin@gmail.com
}

\begin{abstract}
Coconut shell charcoal briquette is one of the solutions in facing the fuel crisis. Indonesia produces a lot of coconut shell waste which can be used as a material for making charcoal briquettes. The purpose of this study was to obtain data on the best quality of coconut shell charcoal briquettes in terms of material density. This information will be important for those who are interested in making briquettes. This study used 3 density variations, namely $0.78 \mathrm{~g} / \mathrm{cm}^{3}$ (D1), 0.92 $\mathrm{g} / \mathrm{cm}^{3}$ (D2), and $1.05 \mathrm{~g} / \mathrm{cm}^{3}$ (D3). The results of this study indicate that the level of material density has no significant effect on moisture content, ash content, volatile substance content, carbon content, and calorific value. However, the level of material density has a significant effect on the compressive strength and burning rate. The highest compressive strength is at D3 (1555.98x104 Pa), then D2 (1229.09x104 Pa), and the lowest is at D1 (565.51x104 Pa). The highest burning rate is at D1 $(0.42 \mathrm{~g} / \mathrm{min})$, then D2 $(0.33 \mathrm{~g} / \mathrm{min})$, and the lowest is at D1 $(0.28 \mathrm{~g} / \mathrm{min})$. These results conclude that the best results were obtained in the D3 treatment, namely at the density level of $1.05 \mathrm{~g} / \mathrm{cm}^{3}$.
\end{abstract}

Keywords: briquettes, coconut shell. coconut shell charcoal.

\begin{abstract}
ABSTRAK
Briket arang tempurung kelapa merupakan salah satu solusi dalam menghadapi krisis BBM. Indonesia banyak menghasilkan limbah tempurung kelapa yang dapat dimanfaatkan sebagai bahan pembuatan briket arang. Tujuan dari penelitian ini adalah untuk mendapatkan data tentang mutu terbaik briket arang tempurung kelapa ditinjau dari segi densitas bahan. Informasi ini dapat berguna bagi masyarakat yang tertarik untuk membuat briket. Dalam penelitian ini, 3 variasi kerapatan (densitas) yang digunakan adalah $0,78 \mathrm{~g} / \mathrm{cm}^{3}$ (D1), 0,92 $\mathrm{g} / \mathrm{cm}^{3}$ (D2), dan $1,05 \mathrm{~g} / \mathrm{cm}^{3}$ (D3). Hasil penelitian ini menunjukkan bahwa tingkat densitas bahan tidak berpengaruh nyata terhadap kadar air, kadar abu, kadar zat menguap, kadar karbon, dan nilai kalor bahan. Meski begitu, tingkat densitas bahan berpengaruh nyata terhadap kuat tekan dan daya bakar bahan. Kuat tekan tertinggi pada D3 $(1555,98 \times 104 \mathrm{~Pa})$, lalu D2 $(1229,09 \times 104 \mathrm{~Pa})$, dan terendah pada D1 (565,51x104 Pa). Daya bakar tertinggi pada D1 (0,42 g/menit), lalu D2
\end{abstract}


(0,33 g/menit), dan terendah pada D1 (0,28 g/menit). Dengan hasil tersebut penulis berkesimpulan bahwa hasil terbaik diperoleh pada perlakuan D3 yaitu pada tingkat densitas $1,05 \mathrm{~g} / \mathrm{cm}^{3}$.

Kata kunci: briket, tempurung kelapa, arang tempurung.

\section{PENDAHULUAN}

Indonesia adalah salah satu negara penghasil kelapa terbesar di dunia. Pada tahun 2019 tercatat luas perkebunan kelapa mencapai 3,4 juta Ha dimana 101,8 ribu Ha terdapat di Provinsi Sulawesi Selatan (BPS, 2019) sehingga kelapa menjadi salah satu potensi industri baik di Sulsel maupun di Indonesia. Industri kelapa umumnya menggunakan daging buah kelapa untuk dijadikan kopra yang diolah menjadi santan dan minyak kelapa. Sementara hasil sampingan lain seperti sabut dan tempurung masih kurang dimanfaatkan. Padahal, kedua hasil sampingan yang biasanya dijadikan limbah masih sangat berguna jika diolah.

Tempurung merupakan salah satu potensi yang terdapat pada kelapa. Dalam tiap buah kelapa terkandung sekitar 15-19\% tempurung (Pugersari, Syarief, \& Larasati, 2013). Tempurung (juga disebut batok) adalah bagian kelapa yang bersifat keras karena mengandung Silikat $\left(\mathrm{SiO}^{2}\right)$, yang memiliki 3 (tiga) buah lubang tumbuh di bagian pangkalnya. Pembentuk tempurung adalah lignin, selulosa, metoksil dan berbagai mineral lainnya, dimana jumlah kandungan bahan pembentuk tempurung tersebut beragam berdasarkan jenis kelapanya. Meski tempurung kelapa umumnya langsung digunakan sebagai pengganti kayu bakar, tempurung kelapa juga dapat diolah terlebih dahulu menjadi arang. Arang yang dihasilkan dari tempurung kelapa dapat digunakan sebagai kayu bakar biasa atau diolah menjadi briket arang hingga arang aktif yang diperlukan oleh berbagai industri pengolahan. Arang tempurung selain dapat digunakan sebagai bahan bakar, juga dapat diolah lebih lanjut menjadi bahan baku industri arang aktif. Briket arang tempurung kelapa dibuat melalui proses pirolisis, penghancuran, pencampuran, pencetakan dan pengeringan, dimana kualitas briket dipengaruhi oleh sifat fisik seperti komposisi, pori-pori, densitas, hingga ukuran partikel briket (Budi, 2011).

Tempurung dapat dimanfaatkan sebagai pengganti bahan bakar. Kenaikan harga bahan bakar minyak (BBM) seringkali menjadi polemik di Indonesia sehingga salah satu solusi untuk masalah ini adalah dengan memanfaatkan limbah pertanian dan perkebunan seperti tempurung kelapa sebagai pengganti bahan bakar. Briket arang tempurung merupakan salah satu industri yang berpotensi memberikan keuntungan bagi masyarakat. Machmud (2011) berargumen bahwa industri arang briket tempurung kelapa sangat layak dijadikan usaha dengan nilai Net Present alue (NVP) yang tinggi dan nilai Internal Rate of Return (IRR) yang melampaui 100 persen. Hal ini juga diperlihatkan oleh Martanto (2016) yang menunjukkan bahwa usaha briket memiliki nilai Benefit-Cost $(\mathrm{B} / \mathrm{C})$ ratio adalah 2,04 (lebih besar dari 1) sehingga layak dijadikan usaha.

Berdasarkan kondisi tersebut, maka penelitian tentang studi pembuatan briket tempurung kelapa perlu dilakukan, karena pemanfaatan tempurung kelapa memiliki prospek yang cukup bagus sebagai salah satu sumber energi biomassa, 
dan juga dapat digunakan sebagai bahan bakar alternatif yang dihasilkan dari teknologi tepat guna. Telah banyak dilakukan penelitian mengenai briket arang, tetapi penelitian mengenai kerapatan bahan masih sangat jarang dilakukan. Padahal, kerapatan sangat erat hubungannya dengan mutu briket yang dihasilkan. Oleh karena itu, perlu diteliti pengaruh kerapatan bahan terhadap mutu briket. Tujuan penelitian ini adalah untuk memperoleh data tentang mutu terbaik briket arang tempurung kelapa ditinjau dari segi densitas bahan. Penelitian ini diharapkan berguna bagi masyarakat yang tertarik untuk membuat briket.

\section{BAHAN DAN METODE}

\section{Waktu dan Tempat}

Penelitian ini dilaksanakan di Laboratorium Dinas Pertambangan dan Energi Makassar dan di Laboratorium Balai Standarisasi Industri dan Perdagangan Makassar.

\section{Alat dan Bahan}

Penelitian ini menggunakan peralatan yaitu neraca listrik, baskom, pengaduk, crusher machine, cetakan, pressing machine, muffle furnace, desikator, shake test driver, jangka sorong, alat ukur tekanan, oven, gelas ukur, mistar, timbangan, plastik bening, dan panci. Bahan yang digunakan pada penelitian ini adalah arang tempurung kelapa, kanji, minyak tanah, dan air.

\section{Analisis Data}

Penelitian dilakukan dengan cara mencetak serbuk arang tempurung kelapa yang dihancurkan, kemudian memperlakukan 3 variasi densitas bahan. Untuk mengetahui besar pengaruh variasi kerapatan bahan terhadap pengujian diatas, digunakan metode RAL (Rancangan Acak Lengkap) tunggal dengan uji lanjut BNT (Beda Nyata Terkecil).

\section{Penelitian Pendahuluan}

Penelitian pendahuluan dilakukan sebelum penelitian utama untuk menentukan konsentrasi kanji yang terbaik diantara tiga variasi yaitu 4\%, 6\%, dan $8 \%$. Hasil terbaik yang diperoleh pada penelitian pendahuluan digunakan dalam penelitian utama. Adapun prosedur penelitian pendahuluan adalah sebagai berikut :

1. Arang tempurung kelapa dihancurkan di dalam crushing machine.

2. Tepung arang diayak untuk menyortir dan mendapatkan ukuran fraksi butir 30 mesh.

3. Arang dicampur dengan kanji yang dimasak dalam $700 \mathrm{ml}$ air, dengan konsentrasi kanji 4\%, 6\%, dan $8 \%$ dari berat arang. Bahan perekat kanji berguna untuk menarik air lalu membentuk formasi briket yang padat.

4. Arang dicetak dengan bentuk silinder, lalu dikempa hingga benar-benar padat menjadi briket.

5. Briket arang yang sudah dikempa lalu dikeringkan dengan cara dimasukkan ke dalam oven selama 5 (lima) jam pada suhu $80^{\circ} \mathrm{C}$.

6. Pengujian dilakukan dengan membakar briket dan menghitung lama pembakaran tiap perlakuan.

\section{Penelitian Utama}

Prosedur Penelitian utama adalah sebagai berikut : 
1. Arang tempurung kelapa dihancurkan dengan ukuran 30 mesh dan dicampur dengan $8 \%$ kanji. Sebagaimana penelitian pendahuluan diperoleh hasil konsentrasi kanji ideal untuk penelitian ini adalah $8 \%$.

2. Arang yang telah dihancurkan dicetak menjadi briket pada perlakuan 3 (tiga) variasi kerapatan bahan (densitas). Densitas yang digunakan adalah $0,78 \mathrm{~g} / \mathrm{cm}^{3}, 0,92 \mathrm{~g} / \mathrm{cm}^{3}$, dan $1,05 \mathrm{~g} / \mathrm{cm}^{3}$.

3. Briket arang yang telah jadi diuji sesuai dengan prosedur pengujian.

Proses dalam penelitian ini dapat dilihat pada bagan alir yang terdapat pada Gambar 1.

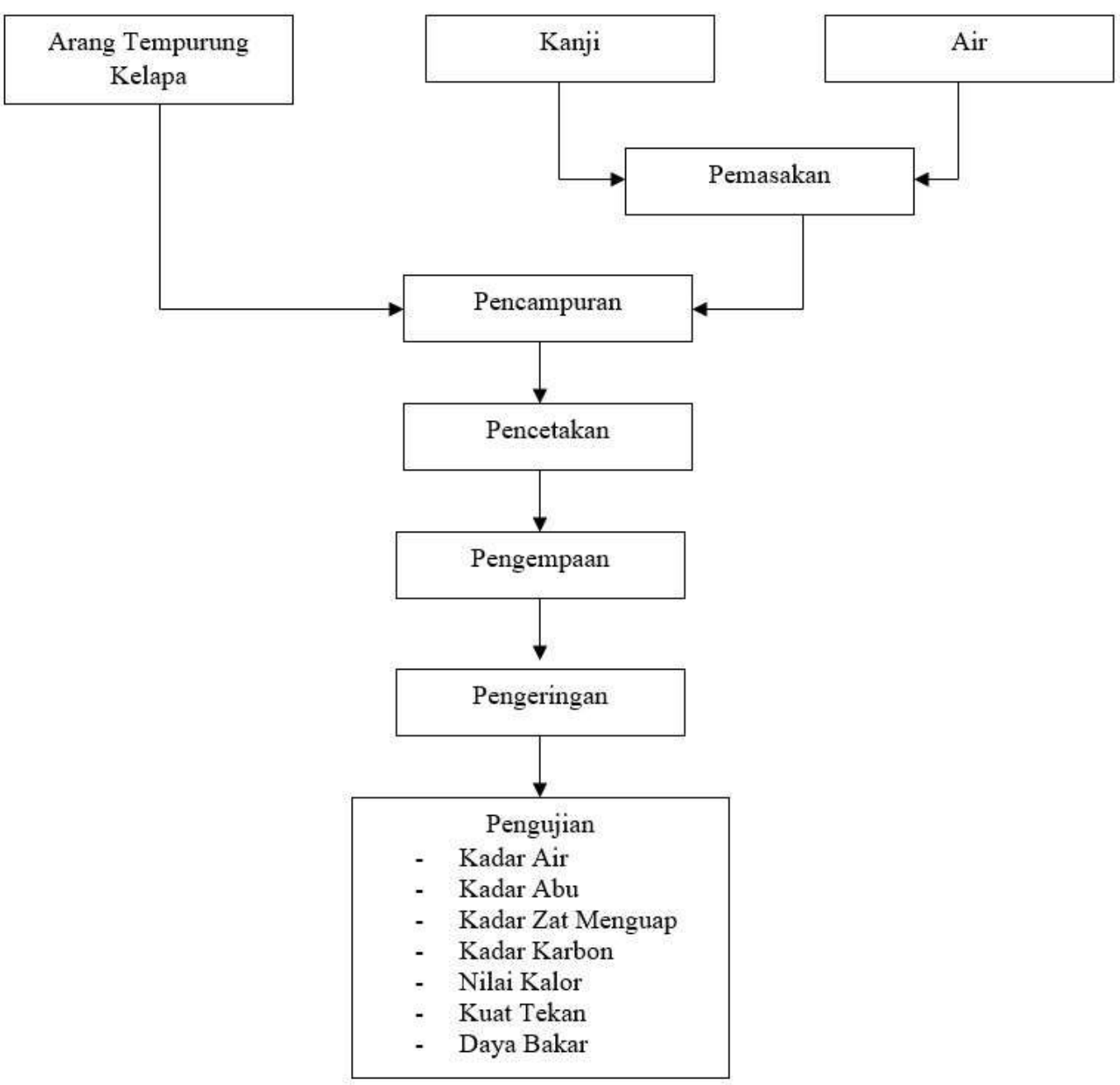

Gambar 1. Bagan Alir Penelitian

Penelitian ini menggunakan tiga perlakuan untuk pembuatan bahan briket arang tempurung kelapa. Perlakuan yang diberikan pada bahan adalah sebagai berikut:

$\mathrm{D} 1=0,78 \mathrm{~g} / \mathrm{cm}^{3}$

$\mathrm{D} 2=0,92 \mathrm{~g} / \mathrm{cm}^{3}$

D3 $=1,05 \mathrm{~g} / \mathrm{cm}^{3}$

Briket dicetak dengan bentuk sebagaimana terlihat pada Gambar 2. Bentuk tersebut disesuaikan dengan alat cetak yang tersedia pada laboratorium pengujian. 


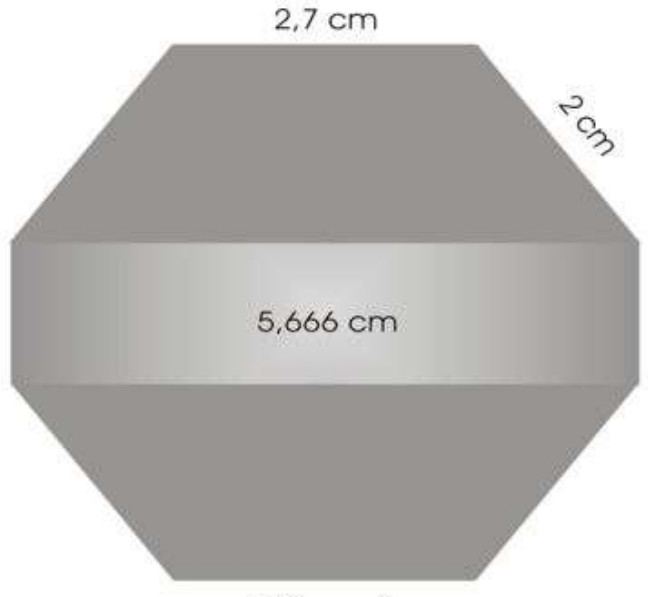

2 Dimensi

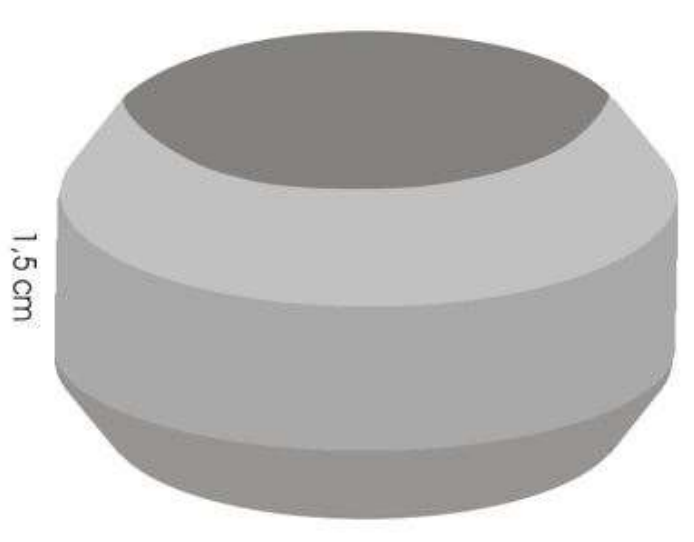

3 Dimensi

Gambar 2. Tampilan 2 Dimensi dan 3 Dimensi Briket dalam Penelitian Ini

\section{Parameter Pengamatan}

\section{Kadar Air (Moisture Content)}

KadarAir $(\%)=\frac{(A-B)}{B} \times 100 \%$

Dimana:

$\mathrm{A}=$ Berat sampel sebelum dikeringkan (gram)

$\mathrm{B}=$ Berat sampel setelah dikeringkan (gram)

\section{Kadar Abu (Ash Content)}

$\operatorname{KadarAbu}(\%)=\frac{(C-D)}{C} \times 100 \%$

Dimana:

$\mathrm{C}=$ Berat sampel sebelum dibakar (gram)

$\mathrm{D}=$ Berat sampel setelah dibakar (gram)

\section{Kadar Zat Menguap (Volatile Matter)}

KadarZatTerbang $(\%)=\frac{E}{F} \quad x \quad 100 \%$

Dimana:

$\mathrm{E}=$ Berat sampel sebelum dibakar (gram)

$\mathrm{F}=$ Berat sampel setelah dibakar (gram)

\section{Kadar Karbon (Fixed Carbon)}

Kadar Karbon dihitung dengan menggunakan rumus berikut :

$\%$ Kadar Karbon $=100 \%-(\%$ K.Air $+\%$ K.Abu $+\%$ K Zat Terbang $)$ 


\section{Nilai Kalor (Calorific Value)}

Nilai kalor bahan diuji melalui penggunaan alat bomb calorimeter.

$$
\text { NilaiKalor }=\frac{(T 2-T 1) x C-\text { Fkoreksi }}{m}
$$

Dimana:

$\mathrm{T} 1=$ Suhu sebelum pembakaran $\left({ }^{\circ} \mathrm{C}\right)$

$\mathrm{T} 2=$ Suhu setelah pembakaran $\left({ }^{\circ} \mathrm{C}\right)$

$\mathrm{C}=$ Kapasitas panas efektif $=2458 \mathrm{kal} /{ }^{\circ} \mathrm{C}$

$\mathrm{m}=$ Berat bahan yang dibakar $(\mathrm{g})$

F koreksi adalah :

1. Panas yang terjadi disebabkan oleh pembakaran kawat.

2. Panas sebagai hasil pembentukan asam nitrat dan asam sulfat.

\section{Daya Tahan}

Pengukuran kuat tekan dilakukan menggunakan pressing machine. Daya tahan bahan merupakan kekuatan penerimaan beban tekanan dimana daya tahan ini dihitung ketika bahan mengalami keretakan ketika ditekan. Nilai daya tahan bahan diambil pada alat tekan tepat ketika bahan yang ditekan retak.

\section{Daya Bakar}

Daya bakar dihitung agar diketahui berapa lama waktu yang dibutuhkan untuk membakar bahan hingga habis (menjadi abu) dengan cara membakar briket hingga membara. Waktu mulai dihitung ketika briket mulai membara hingga bahan briket telah habis menjadi abu.

\section{HASIL DAN PEMBAHASAN}

\section{Kadar Air}

Sebagaimana terlihat pada Gambar 3, hasil pengukuran menunjukkan bahwa kadar air terendah terdapat pada perlakuan (D1) dimana rata-rata kandungan kadar airnya adalah 3,66 \%, lalu perlakuan (D2) yaitu 4,64 \%, dan tertinggi adalah perlakuan (D3) yaitu $5,16 \%$.

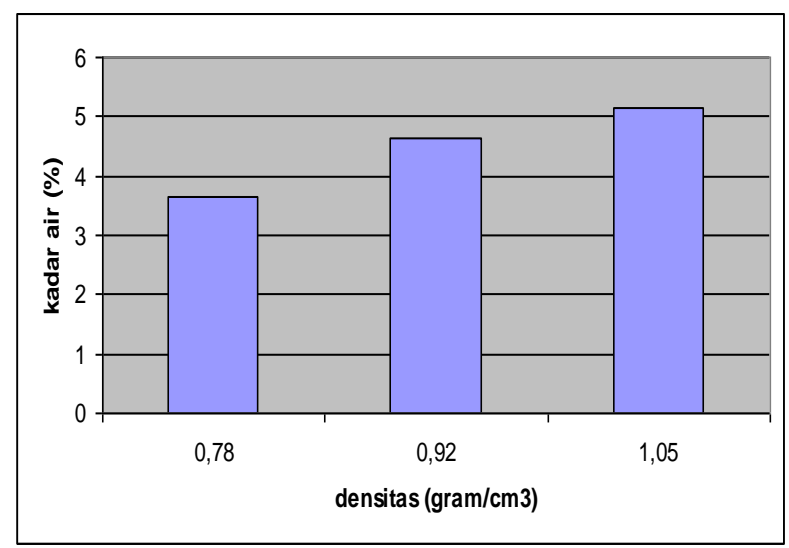

Gambar 3. Hubungan antara Densitas Bahan terhadap Kadar Air Bahan

Perlakuan D1 memiliki pori-pori yang lebih besar sehingga air lebih cepat menguap. Seran (1990) mengatakan bahwa pada waktu pengeringan air akan 
menguap dari dalam briket melewati permukaan, sehingga mengurangi kadar air briket. Namun karena adanya pengempaan, permukaan yang lebih cepat mengering akan mengeras sehingga kurang bisa mengimbangi kecepatan pergerakan air bahan menuju permukaan, selanjutnya air tidak dapat lagi menguap karena terhambat. Hasil pengujian dengan menggunakan uji BNT menunjukkan bahwa perbandingan tiap perlakuan tidak berbeda nyata sehingga tidak terdapat pengaruh densitas bahan terhadap kadar air bahan. Hal ini berbeda dengan hasil penelitian yang dilakukan oleh Pambudi et al. (2018), yang menunjukkan bahwa tekanan mengakibatkan kerapatan bahan dan berpengaruh terhadap kadar air briket. Perbedaan ini mungkin terjadi karena perbedaan bahan dimana pada studi tersebut digunakan briket limbah kayu sengon.

\section{Kadar Abu}

Hasil pengukuran yang ditunjukkan pada grafik batang pada Gambar 4 memperlihatkan bahwa kandungan kadar abu terendah terdapat pada perlakuan (D3) yaitu 15,37\%. Lalu (D1) yaitu 15,8\%, dan (D2) yaitu 16,1\%.

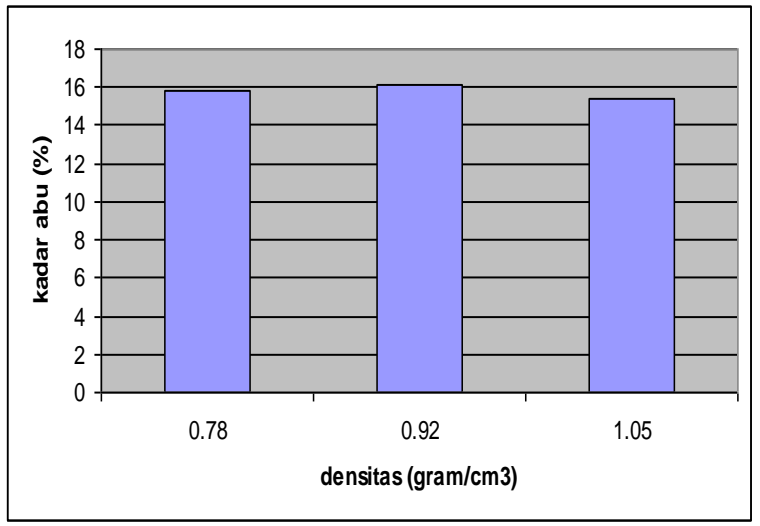

Gambar 4. Hubungan antara Densitas Bahan terhadap Kadar Abu Bahan

Pengujian BNT yang dilakukan menunjukkan bahwa tidak terdapat perbedaan yang nyata terhadap masing-masing perlakuan sehingga dapat terlihat bahwa variabel kerapatan bahan tidak memiliki efek terhadap tinggi rendahnya kadar abu.

\section{Kadar Zat Menguap}

Pengujian pada ketiga perlakuan yang terlihat pada Gambar 5 menunjukkan bahwa kadar zat menguap tertinggi terdapat pada perlakuan (D2) yaitu $12,65 \%$, kemudian (D1) yaitu $12,3 \%$, dan (D3) yaitu $11,78 \%$. 


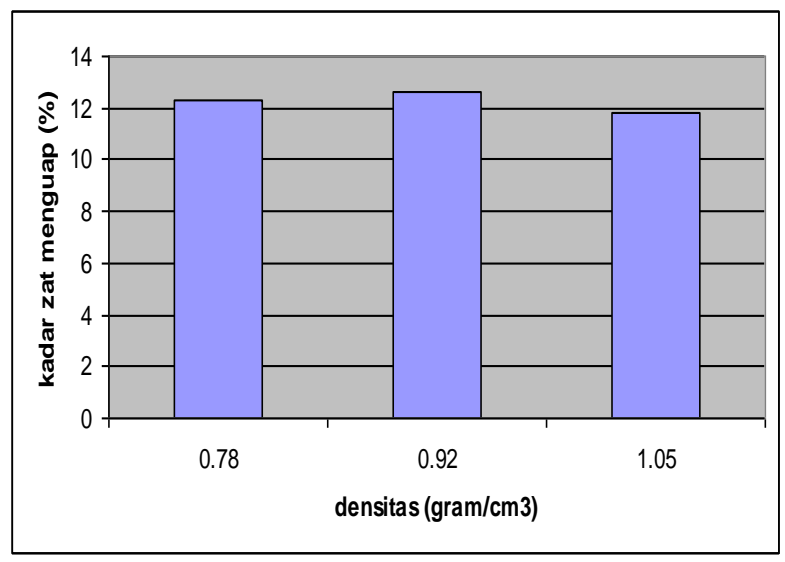

Gambar 5. Hubungan antara Densitas Bahan terhadap Kadar Zat Terbang Bahan

Setelah dilakukan uji lanjut BNT, terlihat bahwa tiap perlakuan tidak berbeda nyata. Kadar zat menguap merupakan beberapa material yang bersifat mudah menguap misalnya metana, hidrogen, dan gas yang tidak mudah terbakar (Trisasiwi, et.al., 2012).

\section{Kadar Karbon}

Persentase kadar karbon dipengaruhi oleh persentase kadar air, kadar abu, dan kadar zat menguap bahan. Gambar 6 yang menunjukkan hasil pengujian kadar karbon memperlihatkan bahwa kadar karbon terbesar terdapat pada perlakuan (D1) yaitu $67.88 \%$, disusul oleh perlakuan (D2) yaitu $67,7 \%$, dan terendah pada perlakuan (D3) yaitu 66,92\%.

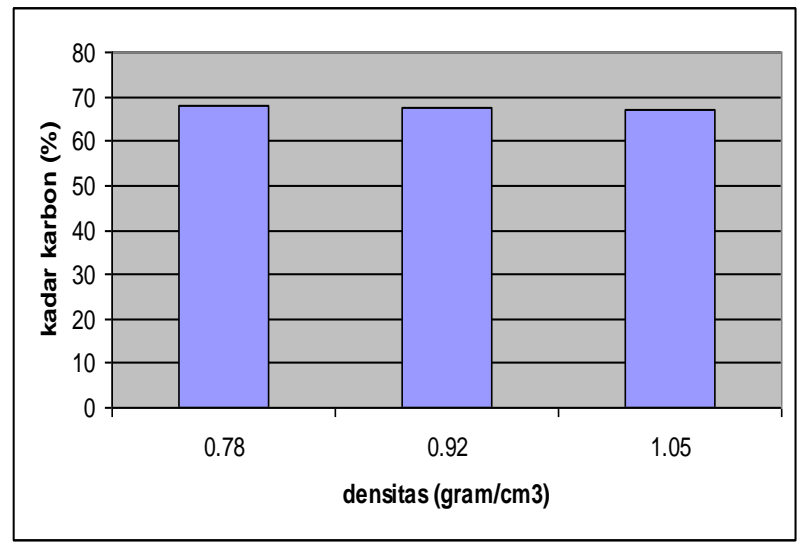

Gambar 6. Hubungan antara Densitas Bahan terhadap Kadar Karbon Bahan

Hasil pengujian BNT yang dilakukan menunjukkan bahwa tidak terjadi beda nyata antara tiap perlakuan sehingga hal itu mengindikasikan bahwa kerapatan bahan tidak berpengaruh terhadap kadar karbon briket. Adapun hasil penelitian Purwanto (2015) menunjukkan bahwa tekanan kempa berpengaruh nyata pada kadar karbon briket limbah tempurung sawit. 
Nilai Kalor

Salah satu indikator untuk menentukan kualitas briket arang adalah nilai kalor. Nilai kalor berkorelasi positif dengan panas yang dihasilkan dimana bahan yang memiliki nilai kalor yang semakin tinggi menghasilkan panas yang juga semakin tinggi. Hasil yang ditunjukkan oleh pengujian (Gambar 7) memperlihatkan bahwa nilai kalor tertinggi terdapat pada perlakuan (D2) yaitu $4220.39 \mathrm{kal} / \mathrm{g}$ kemudian perlakuan (D3) yaitu $4211.19 \mathrm{kal} / \mathrm{g}$, dan terendah terdapat pada perlakuan (D1) yaitu 4203,37 kal/g.

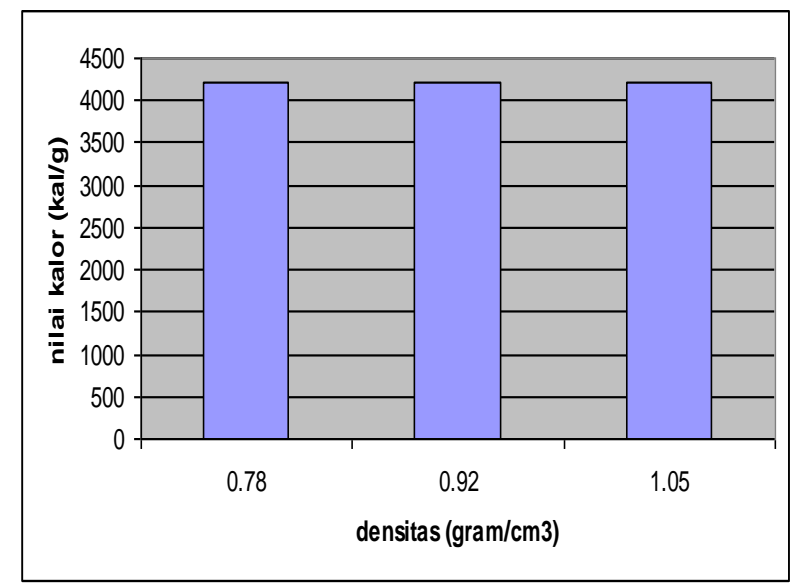

Gambar 7. Hubungan antara Densitas Bahan terhadap Nilai Kalor Bahan

Uji BNT yang dilakukan menunjukkan hasil bahwa tidak terdapat beda nyata pada hubungan antara ketiga perlakuan. Oleh karena itu, dapat disimpulkan bahwa densitas bahan tidak berpengaruh signifikan terhadap nilai kalor briket arang tempurung kelapa.

\section{Daya Tahan}

Berdasarkan hasil pengujian yang dilakukan, terlihat bahwa perlakuan (D3) memiliki daya tahan tertinggi yaitu 1555,98 x104 Pa. Pada Gambar 8, terlihat bahwa perlakuan (D2) memiliki daya tekan 1229,09 x104 Pa, dan (D1) yaitu 565,51 x104 Pa. Kekuatan bahan untuk menerima tekanan mempengaruhi kualitas bahan utamanya pada saat pengemasan. Bahan yang daya tahannya rendah lebih mudah hancur ketika dikemas dibandingkan bahan yang kuat tekannya tinggi.

Uji lanjut BNJ yang dilakukan memperlihatkan bahwa terjadi beda nyata antara perlakuan (D1) terhadap (D2) dan (D3), begitu pula pada perlakuan (D2) berbeda nyata terhadap (D3). Hal ini memperlihatkan bahwa dari sisi kualitas tahan tekanan, perlakuan D3 secara signifikan lebih tinggi dibanding yang lain. Qistina et al. (2016) dalam penelitiannya mengungkapkan bahwa kekuatan tekan briket arang tempurung kelapa lebih tinggi dibandingkan briket sekam padi karena kerapatan partikel lebih tinggi. 


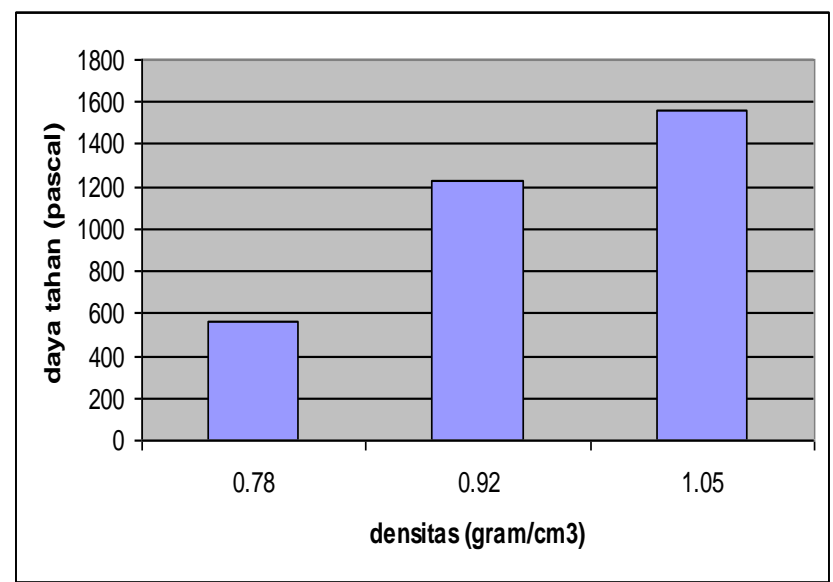

Gambar 8. Hubungan antara Densitas Bahan terhadap Daya Tahan Bahan

\section{Daya Bakar}

Daya bakar yang dimaksud adalah perbandingan antara jumlah bahan pada briket yang terbakar, terhadap waktu yang digunakan selama proses pembakaran briket tersebut. Pembakaran dipengaruhi oleh rongga udara sehingga apabila bahan memiliki rongga yang luas akibat densitas rendah akan lebih banyak bahan yang terbakar. Hasil uji sebagaimana terdapat pada Gambar 9, mengindikasikan bahwa hasil yang terbaik untuk daya bakar diperoleh pada perlakuan (D3). Ratarata lama pembakaran pada perlakuan (D3) adalah $0,28 \mathrm{~g} / \mathrm{menit}$. Hasil terbaik kedua yaitu pada perlakuan (D2) dengan nilai daya bakar $0,33 \mathrm{~g} / \mathrm{menit}$. Perlakuan (D3) menghasilkan daya bakar yaitu $0,42 \mathrm{~g} /$ menit.

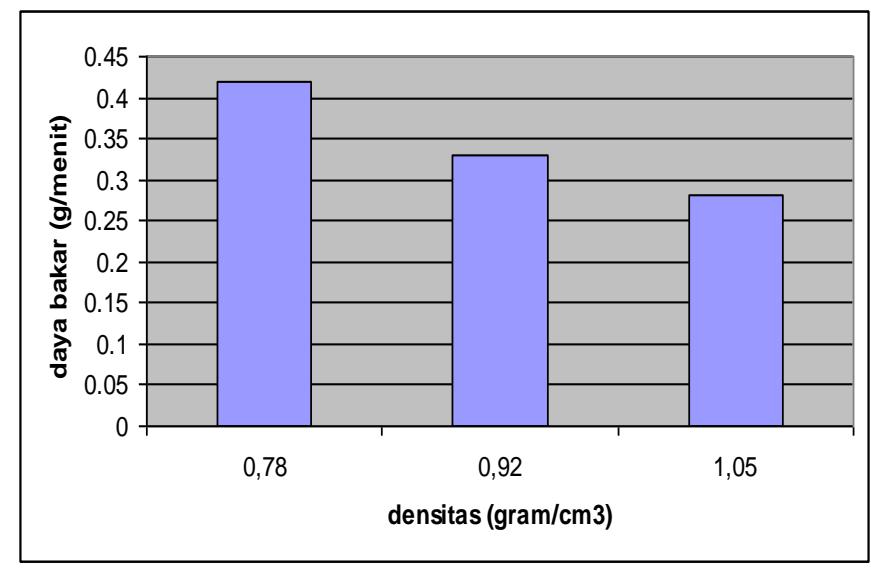

Gambar 9. Hubungan antara Densitas Bahan terhadap Daya Bakar Bahan

Setelah dilakukan uji lanjut, diperoleh bahwa terdapat beda nyata antara perlakuan (D1) terhadap perlakuan (D2) dan (D3). Sementara pada perlakuan (D2) tidak beda nyata terhadap perlakuan (D3). Menurut Setiowati dan Tirono (2014), tempurung kelapa memiliki daya bakar yang sangat baik sebab karakteristik difusi termal karena kandungan selulosa dan lignin yang tinggi pada 
batok kelapa. Hal serupa di jelaskan Prabowo (2009) yang menjelaskan bahwa bahan organik secara proporsional mengandung unsur selulose yang tinggi (50$60 \%$ ) dapat digunakan campuran bahan baku papan olahan dan bahan bakar serta produk lainnya yang dimampatkan.

\section{KESIMPULAN DAN SARAN}

Hasil penelitian ini memberikan beberapa kesimpulan yang dapat ditarik. Pertama, perbedaan densitas bahan berpengaruh nyata terhadap kuat tekan dan daya bakar, dan tidak berpengaruh nyata terhadap kadar air, kadar abu, kadar zat menguap, kadar karbon, dan nilai kalor. Semakin tinggi nilai densitas bahan, samakin lama waktu pembakaran yang terjadi, tetapi semakin sulit bahan tersebut terbakar. Mutu terbaik ditinjau dari daya bakar bahan terdapat pada sampel (D3) yaitu pada kerapatan $1,05 \mathrm{~g} / \mathrm{cm} 3$, dengan nilai daya bakar rata-rata 0,286 gram/menit. Mutu terbaik ditinjau dari daya tahan bahan terhadap tekanan terdapat pada sampel (D3) yaitu pada kerapatan $1,05 \mathrm{~g} / \mathrm{cm} 3$, dengan nilai daya tahan $1555,98 \times 104 \mathrm{~Pa}$.

\section{DAFTAR PUSTAKA}

Badan Pusat Statistik. (2019). Luas Tanaman Perkebunan Menurut Provinsi (Ribu Hektar), 2017-2019. Badan Pusat Statistik 2019. Jakarta-Indonesia.

Budi, Esmar (2011). "Tinjauan Proses Pembentukan dan Penggunaan Arang Tempurung Kelapa Sebagai Bahan Bakar "Jurnal Penelitian Sains Vol 14 No.4 2011 25-29.

Machmud, Senen (2011). "Kajian Ekonomis Industri Briket Arang Tempurung Kelapa”Jurnal Ekonomi, Bisnis \& Entrepreneurship Vol 5 No.1 2011 Hal 4551.

Martanto (2016). "Kajian Aspek Teknis Dan Finasial Usaha Rumah Tangga Briket Biomassa Dari Kulit Nipah Dengan Tempurung Kelapa" Agriekonomika Vol 5 No.1 2016. Hal 94-102.

Pambudi, Feta Kukuh., Nuriana, Wahidin. \& Hantarum, 2018. Pengaruh Tekanan Terhadap Kerapatan, Kadar Air dan Laju Pembakaran pada Biobriket Limbah Kayu Sengon. Prosiding Seminar Nasional Sains dan Teknologi TerapanVI 2018. ISSN 2686-0023.Hal 547-554.

Prabowo, Rossi (2009). Pemanfaatan Limbah Kulit Durian Sebagai Produk Briket di Wilayah Kecamatan Gunung Pati Kabupaten Semarang. Mediagro 5 (1) Hal $52-57$.

Pugersari, Dewi. Syarief, Achmad \& Larasati, Dwinita (2013). "Eksperimen Pengembangan Produk Fungsional Bernilai Komersial Berbahan Baku Tempurung Kelapa Berusia Muda dengan Teknik Pelunakan 'ITB Journal of 
Visual Art and Design Vol 5 No.1 2013. Hal 74-91.

Purwanto, Djoko (2015). "Pengaruh ukuran partikel tempurung sawit dan tekanan kempa terhadap kualitas biobriket"Jurnal Penelitian Hasil Hutan Vol.33No.4 2015 Hal 303-313.

Qistina, Idzni. Sukandar, Dede. \& Trilaksono (2016). "Kajian Kualitas Briket Biomassa dari Sekam Padi dan Tempurung Kelapa Idzni” Jurnal Kimia VALENSI: Jurnal Penelitian Dan Pengembangan Vol 2. No.2 2016. Hal 136142.

Seran, Julius Bria. (1990). Bioarang untuk Memasak. Liberti, Yogyakarta.

Setiowati, Reni.\& Tirono, Mokhamad (2014). "Pengaruh Variasi Tekanan Pengepresan Dan Komposisi Bahan Terhadap Sifat Fisis Briket Arang. Jurnal Neutrino" Jurnal Neutrino Vol 7. No.1 2014 Hal 23-31. https://doi.org/10.18860/neu.v7i1.2636.

Trisasiwi, Wiludjeng. Asnani, Ari. \& Sumanto, Bambang (2012). "Perbaikan Tungku Karbonisasi Model Pembakaran Luar (Retort) Untuk Meningkatkan Kinerja Pengarangan.” Jurnal Tektan Vol 4. No.1 2012. Hal 55-65. 